Narrative Works

Issues, Investigations, \& Interventions

\title{
Different Listener and Teller Positions, Different Narratives
}

\section{Margareta Hydén}

Volume 10, 2020

Special Issue: Amor Narratio: A Festschrift For Catherine Kohler Riessman

URI: https://id.erudit.org/iderudit/1076914ar

DOI: https://doi.org/10.7202/1076914ar

See table of contents

Publisher(s)

Centre for Interdisciplinary Research on Narrative, St. Thomas University

ISSN

1925-0622 (digital)

Explore this journal

Cite this article

Hydén, M. (2020). Different Listener and Teller Positions, Different Narratives. Narrative Works, 10, 12-20. https://doi.org/10.7202/1076914ar
Article abstract

By comparing two interviews with women exposed to their husbands' violence, this article shows that an exploration of the many layers of a personal narrative is not a straightforward linear process, but a circular one. Based on the analysis of one of Catherine Riessman's case stories and one of the author's, the article further shows that a narrative can change dramatically if the tellers' and/or listeners' positions change during the interview.
This document is protected by copyright law. Use of the services of Érudit (including reproduction) is subject to its terms and conditions, which can be viewed online.

https://apropos.erudit.org/en/users/policy-on-use/ 


\title{
NARRATIVE WORKS
}

Issues, Investigations, \& Interventions

\section{SPECIAL ISSUE}

AMOR NARRATIO: A FESTSCHRIFT FOR

CATHERINE KOHLER RIESSMAN

\section{Different Listener and Teller Positions, Different Narratives}

\author{
Margareta Hydén \\ Stockholm University
}

\begin{abstract}
By comparing two interviews with women exposed to their husbands' violence, this article shows that an exploration of the many layers of a personal narrative is not a straightforward linear process, but a circular one. Based on the analysis of one of Catherine Riessman's case stories and one of the author's, the article further shows that a narrative can change dramatically if the tellers' and/or listeners' positions change during the interview.
\end{abstract}

\section{Keywords:}

Positioning, intimate partner violence, personal narrative, teller/listener interaction, interview, multi-layered narrative

\section{Introduction: Searching for Catherine K. Riessman}

New York City, April 16, 1991. The rain is pouring down. X and I are trotting along 34th Street, seeking shelter. We find a bookstore, a great place for a rainy day. "Look here," X says, "this might interest you." He knows me well: the book interests me. I know him well: picking a book for me at a bookstore generally means that he wants to spend considerable time browsing the bookshelves. I find a small uncomfortable chair, have to make an effort not to soak the book completely, and start to read Divorce Talk: Women and Men Make Sense of Personal Relationships by Catherine K. Riessman (C. R.) (1990).

I am overwhelmed by the text. It is written by a scholar who has listened attentively to the personal narratives of men's and women's 
divorce experiences. This is two years before the well-known "little blue book" on narrative analysis (Riessman, 1993) that has been so helpful to many of us. It is my first encounter with this kind of work.

One of the narratives in Divorce Talk was by a woman who had been severely abused by her ex-husband. This narrative spoke directly to me; I was working on my dissertation on intimate partner violence. The reading of "Tessa's Story" opened up a new analytical perspective for me and an interest in applying narrative analysis to my own work.

It had stopped raining. I bought the book and decided that I wanted to contact the author and preferably meet her. But how could I find her? Some vague information about where she might be located was included in the book's preface.

I found 27 names, two study groups and two institutions in the Preface, all acknowledged for contributing to the book. "Catherine Riessman must be a nice person," I thought. "So many people had been so helpful." One of the names stood out a little extra: Elliot Mishler in the Department of Psychiatry at Harvard Medical School. He had been her mentor, had taught her about narrative approaches, and supported her through her project. Maybe he could help me find her? At that point, although I didn't know how to pursue my Riessman/Mishler project, I had no plans to give it up before it had even begun.

A few weeks later, an opportunity opened for me to contact Professor Mishler on the phone. Suddenly, a lunch meeting in Cambridge, Massachusetts, was booked. Over lunch, he asked in the American, straightforward way that is a bit challenging for a Swede: "And what do you want from me?" I couldn't bring myself to be as straightforward as he was, but before the lunch was over, I had received the contact information I needed. I met C. R. some days later. That meeting, almost 30 years ago, was the beginning of our friendship.

Over the years, C. R. has returned to Tessa's story and performed two reanalyses. Her efforts have been richly rewarded. Following Mishler (1986), she regards the interview as a joint product between teller and listener, shaped and organized by asking and answering questions. This approach reflects an open view of the research interview. Since the interview has been my faithful companion in my studies of intimate partner violence, I have read Tessa's story as it appeared in Divorce Talk and the reanalyses, with great interest. The analysis showed that favourable, as well as unfavourable, storylines and corresponding positions were made possible in the interview. When the listener (C. R.) 
changed her position, new storylines were made available and the meaning of the story altered.

I will use the rest of this article to further explore the relationship between changes in the teller's and listener's positions and the new stories that may emerge through such changes. From the analyses of Tessa's story, I will highlight her positions as the surviving teller and as the vulnerable teller, and C.R.'s position as the vulnerable observer. From one of my studies of social network responses to intimate partner violence, I want to present an analysis of Ruth's story, and highlight her change of position from the unloved and disrespected to the loved and respected and show how her changed position changed her story and opened new possibilities for her to act. Finally, I will end the article by some concluding remarks.

\section{The Surviving Teller}

\section{Tessa's Story}

Tessa was a 23-year-old woman who lived under insufficient living conditions. The opening question in the interview about her divorce was: "What were the main causes of the separation?" Quite unexpectedly, she responded by giving a detailed narrative of one of the occasions when her husband insisted that he wanted to have sex with her and finally raped her:

Tessa: When I finally was in bed, I'd just roll over and I wanted to go to sleep. I mean scrubbing the floor every day is kinda rough, you know, you're pretty tired [laugh].

Cathy: Uh-huh.

Tessa: I guess I'm a little sarcastic about it.

Cathy: Uh-huh, I know what you mean.

Tessa: He'd just grab my shoulder and roll me over. I said, "I just don't want it tonight, you know, I just don't want anything tonight." "No, you're my wife and in the Bible, it says you've got to do this."

Cathy: Uh-huh.

Tessa: And after debating for 15 or 20 minutes I grab a pillow, I'd say "I'm going to sleep on the couch, you're not going to leave me alone" and I went and laid on the couch. Two minutes later he was up out of bed and went after me, he had bought me a dozen roses 
[the day before] and he picked the vase of roses and threw the roses at me, poured the water on me.

Cathy: Mm-hmm.

Tessa: and dragged me by the arm from the couch

Cathy: Mm-hmm

Tessa: to the bedroom and then proceeded to make love to me

Cathy: Uh-huh

Tessa: and I didn't know what to do. I tried to push him off me and I tried to roll away

Cathy: Uh-huh

Tessa: ah I tried to cross [laugh] my legs [laugh] and it didn't ...work

Cathy: Uh-huh.

Tessa: He's six foot seven and I'm five eight.

(Riessman, 1990, p. 90).

Her husband's repeated sexual violence provoked a rage in Tessa that finally made her break up the marriage. In C. R.'s analysis of Tessa's story, she identifies the message Tessa wants to convey; she has overcome her powerlessness and victimization and filed for divorce, even though her husband "was completely against it." C. R. (1990) concluded that "Tessa had taken on the identity of a survivor, rather than that of a victim" (p. 93).

\section{Tessa's Story Revisited: The Vulnerable Observer}

When C. R. returns to Tessa's story in 2002, she reflects on her own position as a listener. She recalls that she was totally unprepared for the story of the man's brutality. In her field notes, she had written "moving" and "difficult." Concerns about Tessa intruded her thoughts for months after the interview. She found the anthropologist Ruth Behar's (1996) concept of the "vulnerable observer" useful for understanding her own position when listening to Tessa. She now becomes aware that her strong sense of vulnerability was linked to her own biography: she had witnessed severe violence herself (Riessman, 2002, p. 200).

She recalls that as long as she was in the position of the vulnerable observer, it was difficult for her to bear witness to Tessa's vulnerability. Therefore, she had contributed to the positioning of Tessa as a survivor. Now, 12 years later, she discovers that feelings of insecurity and fear, almost terror, that Tessa had expressed had not been fully included in the 
analysis. In the reanalysis, she includes these feelings and the analysis becomes more elaborate. Tessa is no longer just a survivor, but also a victim of violence and sexual abuse.

\section{The Vulnerable Teller}

In 2015 , C. R. returns to Tessa's story again in an essay on reflexivity and narrative research. She now adds some new material to the analysis, namely Tessa's diary, including drawings of empty beds after her children had been taken into foster care. In this third analysis of the story, C. R. positions Tessa as a mother who had been unable to take care of her children and was mourning the loss. With this position taken into account in her reanalysis, she concludes again that Tessa's story contains further levels of complexity than the survivor narrative that she and Tessa jointly constructed in the interview.

\section{Ruth's Story}

Ruth is a 55-year-old woman who had been subjected to severe psychological and physical violence. The interview took place at the Centre for Victims of Violence in her hometown, where she was attending meetings for women who were victims of intimate partner violence. I received unexpected help with my interview, namely from my dog, a big boxer male named Buster. Due to my bad planning, it turned out that no one could take care of him while I was away for some days of interviewing. "Bring him," said the therapists at the Centre. "We can look after him." I accepted the offer. When Ruth arrived, I introduced him and asked her whether he should stay or go to another room. "Let him stay," she said. "I like dogs." The dog stayed, and Ruth and I commenced the interview.

\section{The Unloved and Disrespected Teller}

Margareta: In front of you, you can see a circle. You'll draw your network into that circle. It is divided into four parts, one for family, one for relatives, one for friends and neighbours, and one for work-related people. Use circles for women and triangles for men. You place yourself at the centre of the circle. 
Ruth: I have to think ... I have some friends and I have some colleagues, but right now I'm on sick leave. I have my two sons, but they have their own lives.

And relatives ... my grandparents are dead. I have three cousins, I can add them, but I have no contact with them. These days, we only meet at distant relatives' funerals. I have good neighbours, but we just say "hallo" and that's it. I'm afraid there aren't that many persons in my network.

Margareta: Who knows about the violence?

Ruth: Maybe no one. Except for the women in the group of victims of violence I join. I don't like to talk about it. I have always had a high level of integrity. I don't like having people too close to me.

Margareta: I see. Is it possible for you to tell me something about the violence?

Ruth: Well ... yes. In the beginning, I didn't really understand what violence was, I think. He used to call me names and pushed me and accused me for various things, like I didn't know how to behave and things like that. It made me confused and depressed.

Margareta: Hmm.

Ruth: Then it got worse. He could hit me and slap me in the face.

Margareta: That was really bad.

Ruth: I know. But to be honest, I must add that I'm not easy to live with. I can do the most unacceptable things.

It was a lonely woman's story Ruth shared with me. By the last utterance, she more or less justified the violence. It seemed like an echo of the man's voice. Ruth tried to control her emotions, but her body betrayed her and exposed her vulnerability, pain, and loneliness. I was just about to propose a more detailed exploration of the "I can do the most unacceptable things" utterance when I suddenly received unexpected assistance.

\section{The Beloved and Respected Teller}

Until then, the dog had slept at the end of the room. We had heard him snoring. Now he woke up, arose, shrugged, and moved towards Ruth. I told him to stop and asked her if I should tell him to step back. She nodded. It was all right for him to move towards her. I told him he could continue. 
The 80-pound guard dog walked up to her, put his head in her lap, and looked at her. She started to cry. Tears wet his head. He did not pay this any noticeable attention. He simply stayed with her. The dog's loyal affection seemed to have blocked the way to the realm of self-hatred she had lived in for so long. With the self-hatred blocked, a space was opened up for stories in accordance with the dog's positioning of her as a person worthy of loyal affection. Does it take a dog to create a space for this kind of repositioning to be established? Could I have accomplished it without the dog's assistance? To put it differently: Is it possible for a human researcher to "do a Buster" and reposition the research subject in this way? Yes, I think it is. Nevertheless, a human researcher can learn a lot about how to create relationally safe spaces from a strong and loyal watchdog with calm and assertive body language. thing":

Still crying, Ruth began to speak about "the most unacceptable

Ruth: I have been unfaithful to my husband. He cannot forgive me. And I cannot forgive myself.

She continued by telling me that some years ago, when her husband's violence had increased and the children had moved away from home, she left her husband. She told a male colleague about the abuse. She received a great deal of support from him, and they became lovers. However, she decided to go back to her husband and was now trapped in a situation in which he constantly accused her of being unfaithful. She could not disagree. They both regarded marital unfaithfulness as morally faulty behaviour, which in her and his view positioned them as equals. They were both morally low-ranked people, he because of his violence, she because of her infidelity. Her position as the unfaithful wife not only justified her husband's violence, but increased his power over her quite dramatically, as well.

I decided to continue to explore Ruth's story. Unlike the dog, I could use words to explore her position as "the unfaithful":

Margareta: Hmm. You're talking about the unacceptable things you may have done. I don't know so much about them, but I know one thing and that is that you use the words "unfaithfulness" and "infidelity" in a weird way. What you call "infidelity" is not what we usually mean when we use that word.

Ruth: What do you mean? I had sex with another man. 
Margareta: Yes, but you had left your husband and met another man. It is what we commonly refer to as "being in a relationship." We don't usually call it "infidelity."

Ruth: Ooooh... (puts her hands to her face and cries even more) Are you sure?

Margareta: Definitely.

After my input - some may call it objection-our conversation continued with Ruth's concluding that I had a point. I might even be completely right. The dog returned to his sleeping state and Ruth and I continued to explore her story from this new starting point. Later, I heard from the therapists at the Centre that Ruth had left her husband.

\section{Concluding Remarks}

Already through my reading of Divorce Talk, it became clear to me that narratives generally are multi-layered. They have an overarching main plot, as well as many subplots, and they include multiple perspectives. The analysis of Tessa's and Ruth's stories confirmed that. What the article shows is that a narrative can change dramatically if the tellers' and/or listeners' positions change. It would be too naïve to think that there were no "false" narratives about personal experiences, because people may lie about their whereabouts, but above all, there are different stories, opening up for new interpretations of old stories and for new stories to be told. Sometimes a new interpretation of an old story can take the form of a "turning point" with the power to change the teller's life, as in Ruth's case.

This article has shown that an exploration of the many layers of a personal narrative is not a straightforward linear process. It rather forms a circular process, beginning with an agreement between teller and listener on the subject of the interview, continuing with a question formulated by the listener, followed by careful listening, carried forward by the listener's open attitude to what the teller has to say, and proceeding with a reflective attitude that may open up another round of exploration. C. R.'s analysis of Tessa's story is a good example of such a process.

\section{Postscript: Finding Catherine K. Riessman}

Over the years, $\mathrm{X}$ and I have continued to travel to the U. S. for work and pleasure. At one point, I reminded Elliot Mishler that I had 
contacted him and hinted that a personal meeting would not be completely wrong. "Maybe this is not the appropriate way to approach a Harvard Professor?" I asked him. "No, it is not," was his straightforward reply. "But we love those who do." Thanks to my ignorance of how to behave in better company, and thanks to Elliot Mishler's kindness, I finally found Catherine K. Riessman. I am forever grateful for that.

\section{References}

Behar, R. (1996). The vulnerable observer: Anthropology that breaks your heart. Beacon Press.

Mishler, E. G. (1986). Research interviewing: Context and narrative. Harvard University Press.

Riessman, C. K. (1990). Divorce talk: Women and men make sense of personal relationships. Rutgers University Press.

Riessman, C. K. (1993). Narrative analysis. Sage.

Riessman, C. K. (2002). Doing justice: Positioning the interpreter in narrative work. In W. Patterson (Ed.), Strategic narrative: New perspectives on the power of personal and cultural stories (pp. 193-214). Lexington Books.

Riessman, C. K. (2015). Entering the hall of mirrors: Reflexivity and narrative research. In A. De Fina and A. Georgakopoulou (Eds.), The handbook of narrative analysis (pp. 219-238). John Wiley \& Sons.

Margareta Hydén, $\mathrm{PhD}$, is Professor Emerita in Social Work at Linköping University, Sweden; a Visiting Professor in Criminology, Stockholm University, Sweden; and a Licenced Psychotherapist. She has also served as Visiting Professor at the Centre for Criminology and Criminal Justice, University of Manchester, UK. Her areas of interest include family violence, narrative, and child studies. Her recent work focuses on social networks' responses to intimate partner violence. She has been internationally acknowledged for her innovative research on violence towards women and is renowned for moving the research field beyond a mere static victim's perspective and for engaging in examinations of the complex ways in which women negotiate their power. She has also studied agency in women's narratives of leaving abusive relationships and has developed narrative approaches for the study of sensitive topics. 